\title{
Article \\ Mineralogical and Chemical Changes after Reduction Roasting of Xinjiang Iron Ore, China
}

\author{
Sayaf Mustafa ${ }^{1,2} \mathbb{D}_{\text {, Liqun Luo }}{ }^{1 *}$, Botao Zheng ${ }^{1}$, Chenxi Wei ${ }^{1}$ and Niyonzima Christophe ${ }^{1}$ \\ 1 Key Laboratory of Mineral Resources Processing and Environment of Hubei, School of Resources and \\ Environmental Engineering, Wuhan University of Technology, Wuhan 430070, China; \\ Sayafmustafa86@oiu.edu.sd (S.M.); zhengbotao@cwcec.com (B.Z.); wcx318@whut.edu.cn (C.W.); \\ nichristophe@whut.edu.cn (N.C.) \\ 2 Department of Mining Engineering, Faculty of Engineering Sciences, Omdurman Islamic University, \\ P.O. Box 10257, Omdurman 382, Sudan \\ * Correspondence: luoliqun@whut.edu.cn
}

check for updates

Citation: Mustafa, S.; Luo, L.; Zheng, B.; Wei, C.; Christophe, N.

Mineralogical and Chemical Changes after Reduction Roasting of Xinjiang Iron Ore, China. Metals 2022, 12, 182. https://doi.org/10.3390/met12020182

Academic Editor: Petros E. Tsakiridis

Received: 15 October 2021

Accepted: 12 January 2022

Published: 19 January 2022

Publisher's Note: MDPI stays neutral with regard to jurisdictional claims in published maps and institutional affiliations.

Copyright: () 2022 by the authors Licensee MDPI, Basel, Switzerland. This article is an open access article distributed under the terms and conditions of the Creative Commons Attribution (CC BY) license (https:// creativecommons.org/licenses/by/ $4.0 /)$.

\begin{abstract}
The mineralogical and chemical changes in Chinese Xinjiang iron ore containing impurities, lead, and zinc as a result of reduction roasting were studied via chemical analysis, optical microscopy, $X$-ray fluorescence (XRF), electron probe microanalysis (EPMA), and energy-dispersive spectroscopy (EDS). Analysis showed that hematite was the main iron-bearing mineral, with small amounts of magnetite and iron silicate; lead impurities were mainly lead oxide and lead-iron alum, while zinc oxide was the main zinc impurity. X-ray fluorescence analysis for raw samples indicated the presence of quartz, hematite, magnetite, chlorite, calcite, and dolomite. The results of the analysis of roasted samples showed an increase in hematite at temperatures of $750{ }^{\circ} \mathrm{C}$ and $950{ }^{\circ} \mathrm{C}$, while the elemental iron increased at a temperature of $1200{ }^{\circ} \mathrm{C}$, along with the conversion of galena to lead oxide and sphalerite to zinc oxide, with a stable quartz ratio. The chemical analysis of the raw sample showed that the TFe grade of the sample was $47.04 \%$, while the contents of harmful $\mathrm{Pb}$ and $\mathrm{Zn}$ impurities were $0.39 \%$ and $0.30 \%$, respectively, both of which exceed the index (less than $0.10 \%$ ) required by the iron industry for raw materials. The content of harmful sulfur impurities was also high, at 1.19\%, which needs to be eliminated or reduced. The results of EPMA and EDS analysis of pre-roasting raw samples showed that chemical compositions vary in different locations in the hematite, magnetite, sphalerite, and galena micro-zones. It has also been observed that quartz is mostly diffused with magnetite and hematite, and sulfur appears in small quantities in most regions. The analysis after roasting showed that the percentages of lead, zinc, and sulfur impurities decreased by a large rate. It is clear that the roasting process plays a major role in removing impurities such as sulfur, which appears in a small percentage after the roasting process, and also helps in oxidizing the impurities of lead and zinc, which helps in removing them.
\end{abstract}

Keywords: mineralogical; reduction roasting; X-ray fluorescence; EPMA; iron; $\mathrm{Pb}$; Zn; impurities

\section{Introduction \\ 1.1. Iron Ore}

Iron is one of the most common elements in the world, and forms $5.6 \%$ of the Earth's crust [1]. China is one of the largest producers of iron ore, where in 2012 the iron ore production amounted to 1.3 billion tons, representing $\sim 45 \%$ of global production [2]. Iron is one of the most abundant minerals, and the most ores in which iron is found are:: magnetite $\left(\mathrm{Fe}_{3} \mathrm{O}_{4}\right)$, hematite $\left(\mathrm{Fe}_{2} \mathrm{O}_{3}\right)$, siderites $\left(\mathrm{FeCO}_{3}\right)$, or limonite $\left(2 \mathrm{Fe}_{2} \mathrm{O}_{3} \cdot 3 \mathrm{H}_{2} \mathrm{O}\right)[3,4]$.

\subsection{Geological Characterization of Xinjiang Iron Ore}

The Xinjiang Uygur region occupies about 1/6 of the total land area in China; it is located in northwest China, where many deposits of gold, copper, iron, zinc, and lead have 
been discovered. Sediments usually show clearly but complex relationships with genetic processes. Ore is produced in volcanic rocks with high iron content. Strong hydrothermal alteration is an important sign of the formation and enrichment of iron ore. Detailed studies of these mineral systems and associated metamorphic rock events and structural deformations would greatly improve our understanding of mineral development in the Xinjiang Uygur region [5].

Fe is extracted from Fe ore and converted into alloys. This metallurgical process is important; the raw materials of the iron-bearing mineral are introduced to the blast furnace $(\mathrm{BF})$, wherein aside from $\mathrm{Fe}$ and $\mathrm{C}$, other elements are also subjected to roasting in the furnace. Therefore, steel is produced by pig iron or hot metal and steel scrap. These methods can be performed using two types of furnaces, namely, basic oxygen (or basic oxygen steelmaking) furnaces, and electric arc furnaces (BOFs and EAFs, respectively). In $\mathrm{BOFs}$, approximately $75 \%$ of Fe comes from the hot metal produced during the BF process. In fact, BOFs play a key role in steel production, producing almost $66 \%$ of the total crude steel. At present, over $93 \%$ of the total Fe production from ores is performed using BOF. BOFs use several Fe ores, such as magnetite $\left(\mathrm{Fe}_{3} \mathrm{O}_{4}\right)$ and hematite $\left(\mathrm{Fe}_{2} \mathrm{O}_{3}\right)$, as iron-bearing raw materials. These materials can use coke, pulverized coal, and lime or limestone as reducing agents, heat sources, and fluxing agents, respectively. BOF ironmaking mainly aims to produce a hot metal with consistent quality [6].

\subsection{Impurities in Iron Ore}

Blast furnace slag usually contains $\mathrm{Zn}, \mathrm{C}, \mathrm{CaO}, \mathrm{S}, \mathrm{Pb}, \mathrm{Cd}, \mathrm{Cr}$, As, and alkali metals $(\mathrm{K}$, $\mathrm{Na}$, etc.) [7]. These elements are associated with iron ores of various kinds, which represent the basic use of furnaces. $\mathrm{Cu}, \mathrm{Ni}, \mathrm{Cr}, \mathrm{Cd}, \mathrm{Pb}$, and $\mathrm{Zn}$ are among the most common heavy metal contaminants of industrial pollution [8,9]. Impacts of impurities are shown according to environmental risk indicator for heavy metals, as follows: $\mathrm{Cd}>\mathrm{Zn}>\mathrm{Cu}>\mathrm{As}>\mathrm{Pb}$ [10]. It has been found that the sequence of harmful elements entering the smelting furnace is $\mathrm{K}$ $>\mathrm{Na}>\mathrm{Zn}>\mathrm{Pb}[11]$.

Impurities of $\mathrm{Pb}$ and $\mathrm{Zn}$ are present in iron, and form complex ores, which are difficult to remove at high temperatures. These impurities lead to a decrease in iron productivity [6], which seriously affects the lifetime of blast furnaces and the benefits of ironmaking [12]. These impurities are easy to reduce or oxidize, and can expand and form lead-containing precipitations and zinc-containing dust, seriously affecting the production of the blast furnace. At present, problems related to the use and recycling of mineral waste are common in all integrated steel mills. The continued emphasis of environmental regulations on landfills and their storage has made the effective management of these wastes a high priority [13]. Direct recycling of the iron waste in the blast furnace (BF) is impeded by its chemistry $(0.1 \% \mathrm{Zn}$ in the charge), as well as by the presence of lead [7]. For effective continuous recycling of iron units, it is necessary to identify their sources, determine their structure, and develop a suitable device/technology for the processing of zinc and lead [14]

Although the iron content of the ore is relatively high in Xinjiang, Yunnan, Guizhou, and other remote iron-ore-producing areas in the west of China, many iron ore areas contain lead and zinc impurities, and the content of lead and zinc in some ores is relatively high [11].

Through a previous study conducted on the effects of lead and zinc impurities on the iron industry, and methods of their removal, it was found that most of the removal methods take place after the iron production. Thus, we decided to conduct experiments to clarify the effect of separation before the iron production.

\section{Experimental}

A sample with a size of $~ 100 \mathrm{~mm}$ was taken from an iron mine in the Xinjiang Uygur Autonomous Region, China; its appearance was reddish-brown. The three-stage and closed crushing processes were used to reduce the size. The appropriate amount of the sample to be observed was cut and polished to form a light sheet under a Nikon Lv100pol polarized 
light microscope. The morphological characteristics and output forms of the minerals in the sample were statistically analyzed under an optical microscope.

The microstructure and microelemental composition of the sample were analyzed with an electronic probe microanalyzer (EPMA) along with a spectrometer manufactured by JEOL Ltd., model number JXA-8230/ INCAX-ACT (energy-dispersive spectrometer) Made in Japan Electronics Co., Ltd. [15].

EPMA techniques offer the option of identifying and investigating phases and segregations of a sample material [16]. These techniques are focused on analyzing the microstructure and microelemental composition of samples from the Xinjiang region by electron microscope. The constituent elements were determined by the characteristic wavelength of each element in both raw and roasted samples.

Reduction roasting is now a subject of interest in treating many low-grade ores [17]. Several factors affect roasting processes, such as temperature, time, and usage of carbon in iron recovery. Thus, these roasting conditions must be optimized and controlled [18,19]. The recovery of iron is influenced by the time of roasting [20]. As can be seen, the time of roasting, temperature, and flow rate have significant effects on the decomposition of zinc ferrite [21]. Reduction roasting was used to study changes in metal properties, and to examine the effects of removing lead and zinc impurities from Xinjiang iron ore.

Magnetization reduction roasting/weak magnetic separation is an effective method to treat difficult-to-select hematite. High-temperature reduction roasting is used to directly reduce $\mathrm{Fe}_{2} \mathrm{O}_{3}$ in the ore to magnetic iron, or even elemental iron. Due to the strong magnetism of artificial magnetite and elemental iron, they are separated from the gangue minerals by grinding and dissociating, and the method of weak magnetic separation is used to obtain reduced iron ore powder mainly composed of magnetite or elemental iron. The reaction principle depends on the reduction temperature; from low to high, the reduction occurs in the order of $\mathrm{Fe}_{2} \mathrm{O}_{3} \rightarrow \mathrm{Fe}_{3} \mathrm{O}_{4} \rightarrow \mathrm{FeO} \rightarrow \mathrm{Fe}$. At the same time, the lead and zinc impurities contained in iron ore will simultaneously undergo oxidation and reduction reactions during the roasting process. Although the boiling points of elemental lead and zinc are $1749{ }^{\circ} \mathrm{C}$ and $907^{\circ} \mathrm{C}$, respectively, when the temperature is low, elemental lead is highly volatile, and flows away with the air.

Each ore sample was weighed to $40 \mathrm{~g}$ with a $0.01 \mathrm{~g}$ balance, mixed with coal powder, and then the mixture was placed a quartz crucible and covered to maintain a sufficient reducing atmosphere. The sample crucible was placed in a high-temperature furnace to perform a reduction test, and the temperature was set to increase to $750{ }^{\circ} \mathrm{C}$; after the roasting reaction was completed, the sample was taken out and quickly quenched, before being dried at a low temperature $\left(60^{\circ} \mathrm{C}\right)$. A portion of the sample was taken and ground to $\sim 0.037 \mathrm{~mm}$, accounting for $90 \%$, and the magnetic field strength was $120 \mathrm{kA} / \mathrm{m}$. Subsequently, magnetic separation was performed to obtain the corresponding sorting products. The same experiment was conducted for other temperatures.

\section{Results and Discussion}

\subsection{Chemical Characterization}

Table 1 shows the total iron (TFe), along with the contents of harmful $\mathrm{Pb}$ and $\mathrm{Zn}$ impurities, which exceed the index of $0.10 \%$ required from raw materials in the iron industry. The content of harmful sulfur impurities is also high, and needs to be eliminated or reduced, as do the contents of the gangue mineral components $\mathrm{SiO}_{2}$ and $\mathrm{Al}_{2} \mathrm{O}_{3}, \mathrm{Chemical}$ analysis was carried out via AAS and ICP-MS.

Table 1. Chemical analysis result of raw sample/(mass fraction, \%).

\begin{tabular}{|c|c|c|c|c|c|c|c|c|}
\hline Chemical Composition & $\mathrm{TFe}$ & $\mathrm{FeO}$ & $\mathrm{Pb}$ & $\mathrm{Zn}$ & $S$ & $\mathrm{P}$ & $\mathrm{CaO}$ & $\mathrm{MgO}$ \\
\hline Content & 47.04 & 1.25 & 0.39 & 0.30 & 1.19 & 0.099 & 2.62 & 1.89 \\
\hline Chemical composition & $\mathrm{Mn}$ & $\mathrm{Cu}$ & $\mathrm{SiO}_{2}$ & $\mathrm{Al}_{2} \mathrm{O}_{3}$ & $\mathrm{~K}_{2} \mathrm{O}$ & $\mathrm{Na}_{2} \mathrm{O}$ & C & $\operatorname{Ig}$ \\
\hline Content & 0.66 & 0.110 & 20.33 & 2.85 & 0.843 & 0.783 & 0.31 & 2.81 \\
\hline
\end{tabular}




\subsection{Mineralogical Characterization}

\subsubsection{Iron Ores}

Through the microscopic analysis, we found that the main minerals in the ore were magnetite, hematite, goethite $\mathrm{FeO}(\mathrm{OH})$, and limonite. Magnetite $(\mathrm{Mt})$ accounted for $\sim 15 \%$, with a semi-self-shaped structure (Figure 1a,b). We also observed small amounts of pyrite, sphalerite, pyrrhotite, spinel, and natural iron. Pyrite (Py) accounted for $\sim 1 \%$, with a self-formed or semi-self-shaped granular structure. Pyrrhotite (Po) was also present in a small amount, with an irregular granular shape that is replaced by limonite along the edges (Figure 1c,d).
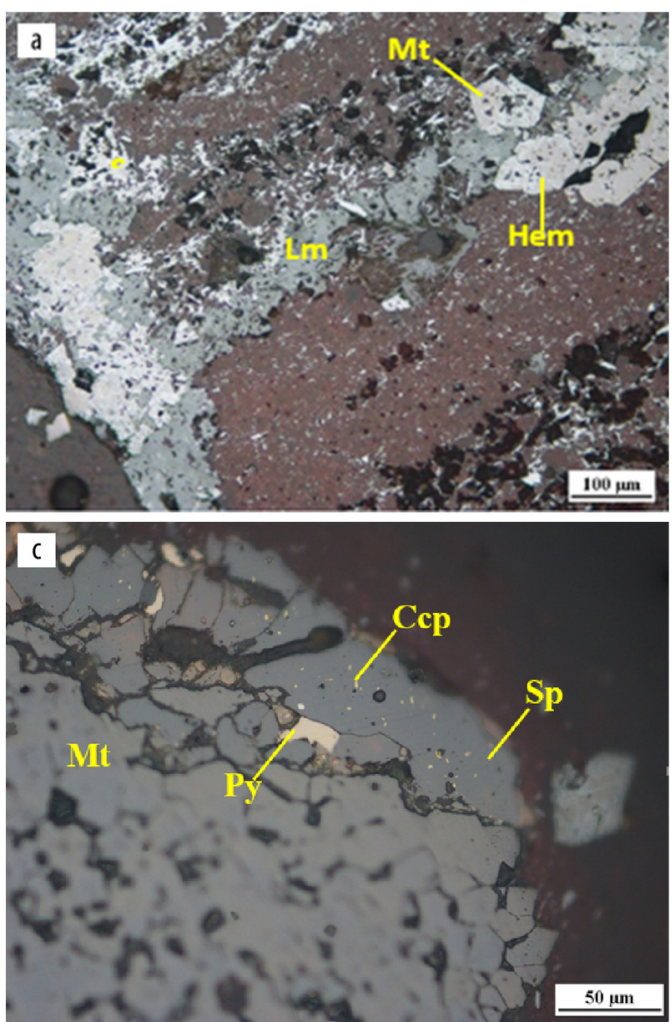
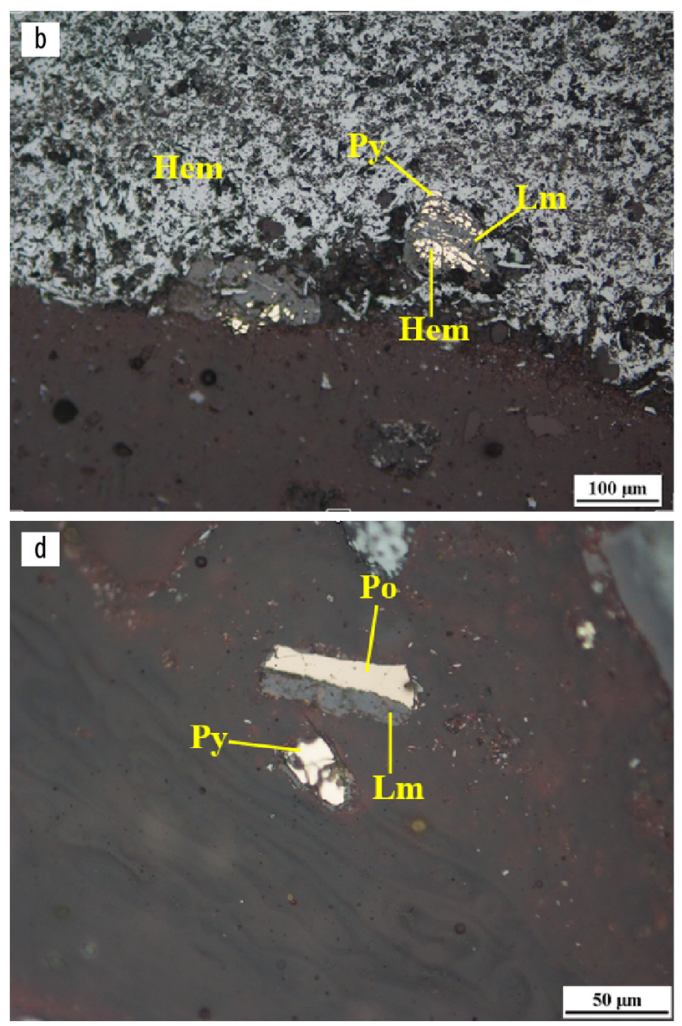

Figure 1. Distribution of the main minerals in the studied sample: (a) magnetite (Mt) and hematite (Hem) structure; (b) minerals permeating the hematite structure; (c) small amounts of pyrite (Py), sphalerite (Sp), pyrrhotite, spinel, chalcopyrite (Ccp) and natural iron; (d) a small amount of pyrrhotite (Po), with an irregular granular shape.

\subsubsection{Lead/Zinc Impurities}

Microscopically, a small amount of galena (Gn) was distributed in an irregular, granular fashion along the transparent mineral grains in the rock fissures; as shown in Figure 2a, this exists as a filling structure. Sphalerite occurs in irregular granular form, and chalcopyrite $(\mathrm{Ccp})$ is especially found within sphalerite in opaque form (Figure $2 b$ ), showing solid solution decomposition structure, and metasomatizing magnetite and hematite. Although the phase analysis of lead and zinc shows that more than $90 \%$ of the impurities of lead and zinc exist in oxidized forms, no crystalline minerals with oxidized states of lead and zinc were found under the microscope. The results of microscopic identification show that the oxidation of the ore is more intense in the later stage; the mineralization of limonite (iron cap) is intense, and the suspected oxidation state of lead and zinc may be sporadically distributed in oxidation zones such as limonite, showing the characteristics of metasomatism or residual leaching. The suspected areas containing lead and zinc oxide were delineated under the microscope and then scanned by EMPA and EDS, before being analyzed and identified by microanalysis. 

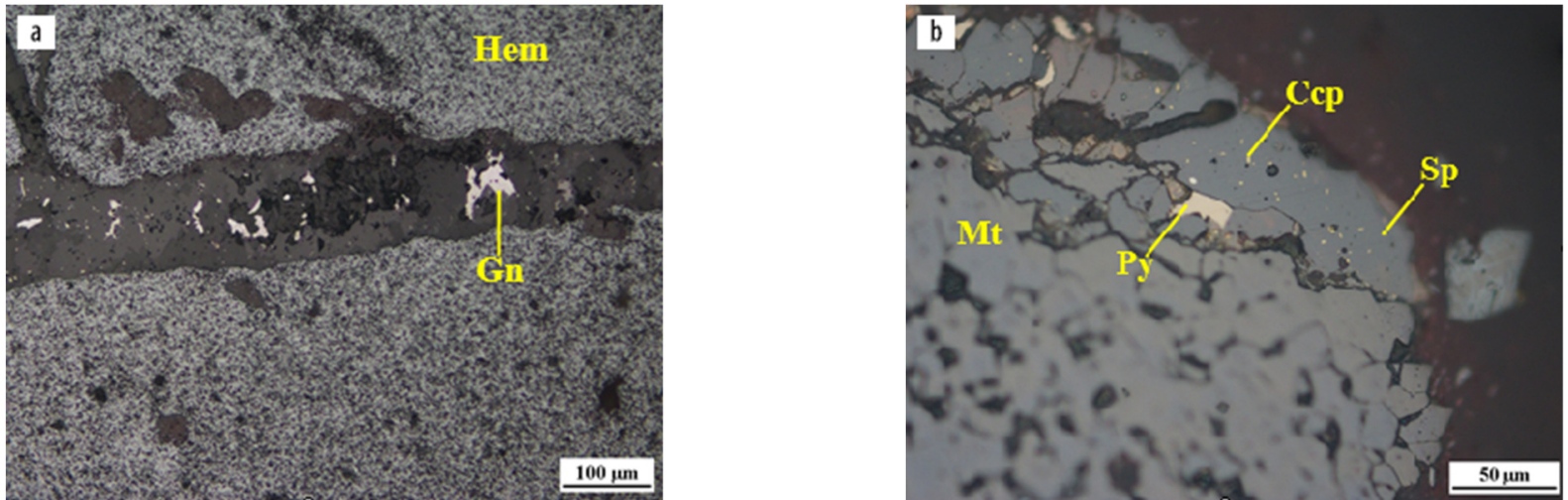

Figure 2. Microscopic photos of lead and zinc mineral impurities in raw ore samples: (a) irregular granular galena (Gn) with interstitial structure; (b) turbid chalcopyrite (Ccp) distributed in irregular granular sphalerite $(\mathrm{Sp})$.

\subsubsection{Roasted Sample}

Through microscopic analysis of samples roasted at different temperatures, the percentages of the main minerals vary with temperature, as do the percentages of impurities. The first sample was roasted at $750{ }^{\circ} \mathrm{C}$ for $60 \mathrm{~min}$, and then a microscopic study was conducted, the results of which showed that the main minerals in the sample were magnetite, hematite, fullerene, and limonite, with small amounts of pyrite, sphalerite, galena, and chalcopyrite (Figure 3a).
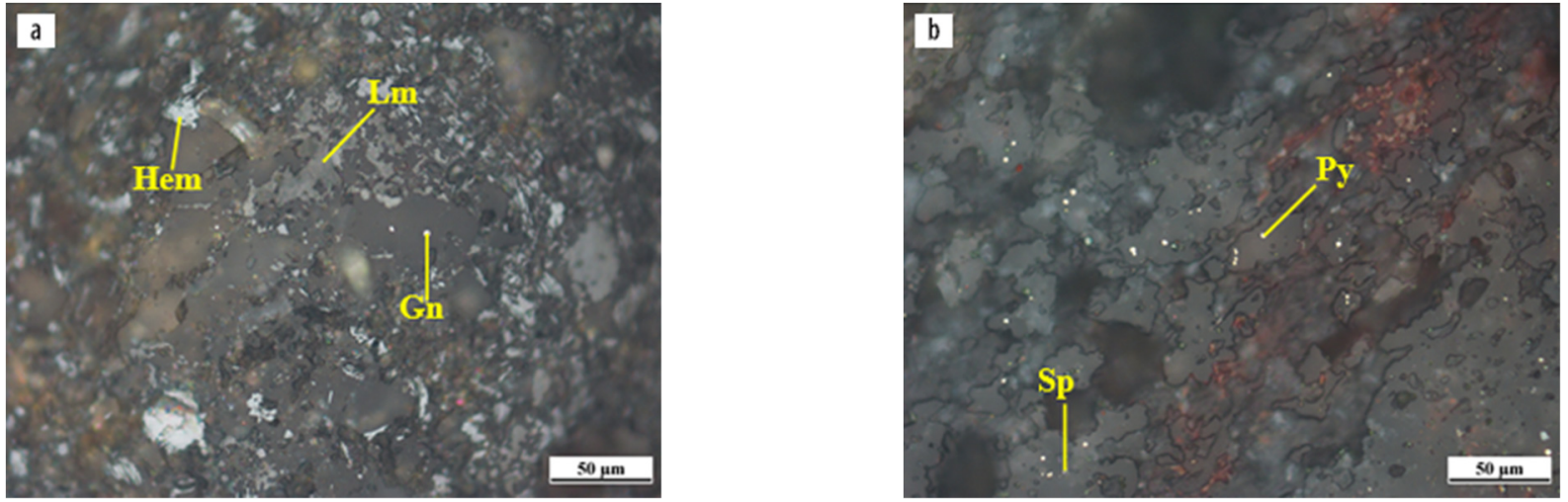

Figure 3. Microscopic images of a roasted sample at $750{ }^{\circ} \mathrm{C}$ : (a) distribution of hematite (Hem), limonite (Lm), and galena (Gn); (b) irregular distribution of sphalerite (Sp) and pyrite (Py).

Magnetite accounts for $12 \mathrm{vol} . \%$, and appears in a semi-automorphic to allomorphic granular form, with the particle size ranging between $\sim 0.002$ and $0.2 \mathrm{~mm}$. Hematite (Hem) $(\sim 36 \%)$ has a semi-automorphic to allomorphic granular structure, with fine acicular crystal morphology and a particle size between 0.002 and $0.1 \mathrm{~mm}$. Sphalerite (Sp) is irregularly distributed, with a particle size between 0.002 and $0.01 \mathrm{~mm}$. Galena $(\mathrm{Gn})$ has an irregular granular distribution in transparent minerals, with particle size between 0.002 and $0.01 \mathrm{~mm}$.

The second sample was roasted at $900{ }^{\circ} \mathrm{C}$ for $60 \mathrm{~min}$; the main minerals in the sample were hematite, fullerene, and pyrite, along with small amounts of sphalerite, galena, smithsonite, limonite, and copper blue.

Hematite (Hem) accounts for $\sim 5 \%$, with a semi-automorphic to allomorphic granular structure, fine tabular crystals, and a particle size of $0.002-0.1 \mathrm{~mm}$.

$\mathrm{FeO}$ accounts for $65 \%$, appearing as an irregular granular structure, strongly metasomatic with hematite and magnetite, and partially metasomatic with pyrite, limonite, etc., in angular, veinlet, or inclusion structures, with a particle size ranging from 0.002 to $0.1 \mathrm{~mm}$. 
Sphalerite (Sp) is very small, and has an irregular granular distribution in transparent minerals, with a particle size of $0.002 \sim 0.03 \mathrm{~mm}$.

Galena (Gn) appears in trace amounts with irregular granular distribution in transparent minerals, occasionally associated with sphalerite; its particle size ranges between 0.002 and $0.02 \mathrm{~mm}$.

Limonite (Lm) accounts for $\sim 3 \%$, and has an irregular, granular, metasomatic distribution along the gap or fracture of pyrite and fullerene particles; the aggregate size is from 0.002 to $0.1 \mathrm{~mm}$ (Figure 4 ).
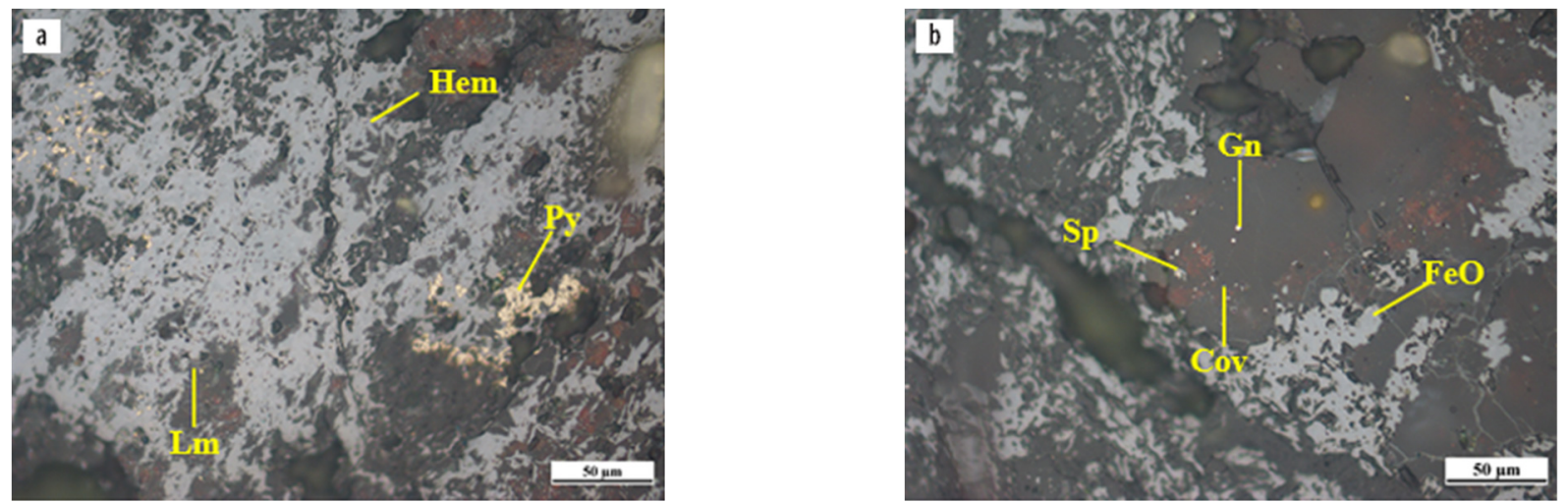

Figure 4. Microscopic images of a roasted sample at $900{ }^{\circ} \mathrm{C}$ : (a) Hematite (Hem), Limonite (Lm), and pyrite (Py) granules; (b) granules of galena (Gn), sphalerite (Sp), and FeO.

The third sample was roasted at $1200{ }^{\circ} \mathrm{C}$ for $60 \mathrm{~min}$; the main minerals in the sample were natural copper, magnetite, galena, limonite, etc., with more carbonaceous residues.

Magnetite (Mt) appears in small amounts, in a semi-automorphic to allomorphic granular form, distributed among the transparent mineral particles, and may be formed by recrystallization; the particle size is between 0.002 and $0.1 \mathrm{~mm}$.

Elemental iron (Fe) accounts for $\sim 58 \%$; it is obviously formed by recrystallization, with a smooth edge. The aggregate particle size is between 0.002 and $0.3 \mathrm{~mm}$.

Galena (Gn) appears in trace quantities, showing an irregular granular distribution in transparent minerals, with a particle size ranging between 0.002 and $0.01 \mathrm{~mm}$.

Limonite (Lm) account for $\sim 2 \%$, with an irregular granular structure, along with the natural iron ball; the aggregate size ranges from 0.002 to $0.05 \mathrm{~mm}$ (Figure 5).
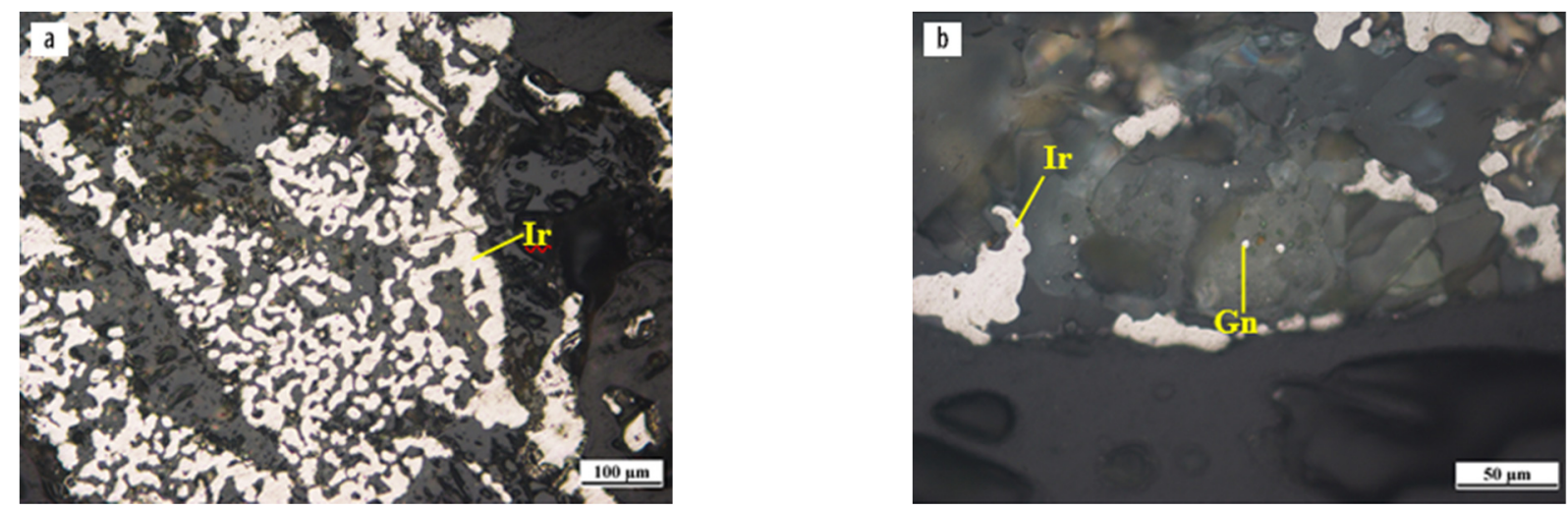

Figure 5. Microscopic images of a roasted sample at $1200^{\circ} \mathrm{C}$ : (a) dense appearance of iron granules; (b) small granules of galena $(\mathrm{Gn})$ with iron granules. 


\subsection{X-ray Fluorescence}

\subsubsection{XRF of Raw Sample}

The main metallic minerals in the ore were hematite $\left(\mathrm{Fe}_{2} \mathrm{O}_{3}\right)$, limonite, and magnetite, with small amounts of pyrite, sphalerite ( $\mathrm{Zn}, \mathrm{Fe}) \mathrm{S}$, and galena $\mathrm{PbS}$, and traces of pyrrhotite, chalcopyrite, tetrahedrite, and copper blue. The content of transparent minerals was $\sim 28-30 \%$, and the main component in it was quartz. The main mineral compositions and their contents are shown in Table 2.

Table 2. Compositions and contents of main minerals in the raw sample/(mass fraction, \%).

\begin{tabular}{cccc}
\hline Minerals & Content & Minerals & Content \\
\hline Hematite & 53.0 & Copper-bearing minerals & 0.3 \\
Limonite & 7.5 & Quartz & 18.6 \\
Magnetite & 4.6 & Feldspar & 7.5 \\
Pyrite, pyrrhotite & 1.1 & Calcite, chlorite, actinolite & 2.5 \\
Sphalerite & 0.4 & Sericite, biotite & 2.7 \\
Galena & 0.3 & Others & 1.5 \\
\hline
\end{tabular}

\subsubsection{XRF of Roasted Samples}

Table 3 represents the results of XRF analysis for roasted samples at $750{ }^{\circ} \mathrm{C}, 900{ }^{\circ} \mathrm{C}$, and $1200^{\circ} \mathrm{C}$. The results of the analysis show that the main metallic minerals in the roasted samples were hematite and total iron (TFe), with small amounts of sphalerite, galena, manganese oxide, and chalcopyrite, in addition to the presence of quartz in large percentages.

Table 3. Compositions and contents of main minerals for roasted samples/(mass fraction, \%).

\begin{tabular}{|c|c|c|c|c|c|c|c|}
\hline Minerals & $750^{\circ} \mathrm{C}$ & at $900^{\circ} \mathrm{C}$ & $1200^{\circ} \mathrm{C}$ & Minerals & $750^{\circ} \mathrm{C}$ & at $900^{\circ} \mathrm{C}$ & $1200^{\circ} \mathrm{C}$ \\
\hline $\mathrm{CO}_{2}$ & 4.776 & -1.686 & -14.265 & $\mathrm{CaO}$ & 1.834 & 1.569 & 1.942 \\
\hline $\mathrm{Na}_{2} \mathrm{O}$ & 0.313 & 0.294 & 0.254 & $\mathrm{TiO}_{2}$ & 0.152 & 0.121 & 0.175 \\
\hline $\mathrm{MgO}$ & 0.655 & 0.445 & 0.516 & $\mathrm{MnO}$ & 0.943 & 1.458 & 0.98 \\
\hline $\mathrm{Al}_{2} \mathrm{O}_{3}$ & 4.578 & 3.478 & 4.232 & $\mathrm{Fe}_{2} \mathrm{O}_{3}$ & 59.777 & 70.202 & TFe 44.134 \\
\hline $\mathrm{SiO}_{2}$ & 20.914 & 16.889 & 21.377 & $\mathrm{CuO}$ & 0.151 & 0.171 & 0.109 \\
\hline $\mathrm{P}_{2} \mathrm{O}_{5}$ & 0.277 & 0.307 & 0.244 & $\mathrm{ZnO}$ & 0.337 & 0.343 & 0.128 \\
\hline $\mathrm{SO}_{3}$ & 2.009 & 1.395 & 1.648 & $\mathrm{BaO}$ & 2.064 & 1.994 & 2.556 \\
\hline $\mathrm{K}_{2} \mathrm{O}$ & 0.809 & 0.634 & 0.835 & $\mathrm{PbO}$ & 0.32 & 0.318 & 0.032 \\
\hline
\end{tabular}

\subsection{Phase Properties of Iron Ores and Lead/Zinc Minerals}

Phases with specific physical and chemical properties in the material, and the phase state of the mineral, are the important factors that normally affect the beneficiation method and technical indicators. Therefore, the results of the phase analysis of iron-bearing minerals and harmful lead/zinc mineral impurities are shown in Tables 4-6.

Table 4. Iron mineral phase analysis of raw sample/(mass fraction, $\%$ ).

\begin{tabular}{ccccccc}
\hline Iron Phase & Magnetite & Hematite/Limonite & Siderite & Sulfide Minerals & Ferric Silicate & Total Fe \\
\hline Fe content & 1.89 & 42.97 & 0.067 & 0.10 & 2.01 & 47.04 \\
Distribution & 4.02 & 91.35 & 0.14 & 0.21 & 4.27 & 100.00 \\
\hline
\end{tabular}

Table 5. Lead phase analysis results in raw sample/(mass fraction, \%).

\begin{tabular}{cccccc}
\hline Lead Phase & Lead Sulfide & Lead Oxide & Lead Sulfate (Alum) & Plumbojarosite & Total Pb \\
\hline $\mathrm{Pb}$ content & 0.028 & 0.19 & 0.0095 & 0.16 & 0.39 \\
Distribution & 7.23 & 49.03 & 2.45 & 41.29 & 100.00 \\
\hline
\end{tabular}


Table 6. Zinc phase analysis results in raw sample/(mass fraction, \%).

\begin{tabular}{cccccc}
\hline Zinc Phase & Zinc Sulfide & Zinc Oxide & Zinc Sulfate & Zinc-Iron Spine & Total Zn \\
\hline Zn content & 0.017 & 0.27 & 0.0023 & 0.0087 & 0.30 \\
Distribution & 5.71 & 90.60 & 0.77 & 2.92 & 100.00 \\
\hline
\end{tabular}

Iron in the sample mainly exists in the form of hematite, with an iron content of $42.97 \%$, and a distribution rate of $91.35 \%$ of the total iron, followed by magnetite with $1.89 \%$ and iron silicate $\left(\mathrm{Fe}_{2} \mathrm{O}_{4} \mathrm{Si}\right)$ with $2.01 \%$, while iron sulfide and iron carbonate are present in minor amounts. Hematite and magnetite are the main sources of iron in the separation process, with a proportion of $95.37 \%$. Lead-containing impurities are mainly present in the form of lead oxide and jarosite, accounting for $49.03 \%$ and $41.29 \%$, respectively, for a total of $90.32 \%$; meanwhile, zinc oxide is the main zinc-containing impurity, accounting for $90.60 \%$. Lead in zinc sulfide is less, accounting for $7.23 \%$ and $5.71 \%$. Because the existence of lead and zinc impurities is harmful to the iron-making process, it is expected that most sulfur can be removed at the same time as removing lead and zinc impurities.

\subsection{Electron Probe Microanalysis (EPMA)}

The results of the analysis are shown in the pictures below. Tables 7-12 show values for points taken at the level of ore samples and samples after roasting. Each metal in the samples appears in a different color and different grain gradation.

Table 7. Electron microprobe analyses of selected spots from area 1 (wt.\%).

\begin{tabular}{cccccccccccc}
\hline Points & $\mathbf{O}$ & $\mathbf{A l}$ & $\mathbf{S i}$ & $\mathbf{S}$ & $\mathbf{C a}$ & $\mathbf{C r}$ & $\mathbf{M n}$ & $\mathbf{F e}$ & $\mathbf{C u}$ & $\mathbf{Z n}$ & $\mathbf{P b}$ \\
\hline P4 & 22.28 & 0.00 & 0.00 & 0.00 & 0.10 & 0.00 & 0.00 & 77.62 & 0.00 & 0.00 & 0.00 \\
P10 & 11.12 & 0.00 & 0.00 & 0.00 & 0.00 & 0.00 & 0.47 & 88.41 & 0.00 & 0.00 & 0.00 \\
P18 & 10.65 & 0.00 & 0.00 & 0.00 & 0.00 & 0.31 & 0.54 & 88.49 & 0.00 & 0.00 & 0.00 \\
\hline
\end{tabular}

Table 8. Electron microprobe analyses of selected spots from area 2 (wt.\%).

\begin{tabular}{cccccccccccc}
\hline Points & $\mathbf{O}$ & $\mathbf{A l}$ & $\mathbf{S i}$ & $\mathbf{S}$ & $\mathbf{C a}$ & $\mathbf{C r}$ & $\mathbf{M n}$ & $\mathbf{F e}$ & $\mathbf{C u}$ & $\mathbf{Z n}$ & $\mathbf{P b}$ \\
\hline P2 & 8.76 & 0.00 & 0.83 & 0.00 & 0.16 & 2.35 & 0.00 & 5.30 & 0.00 & 0.82 & 81.78 \\
P17 & 7.33 & 0.00 & 0.00 & 0.00 & 0.31 & 0.56 & 0.00 & 2.13 & 2.45 & 0.75 & 86.48 \\
P23 & 7.24 & 0.31 & 0.99 & 5.59 & 0.00 & 2.13 & 0.00 & 1.56 & 5.95 & 0.00 & 76.25 \\
\hline
\end{tabular}

Table 9. Electron microprobe analyses of selected spots from area 3 (wt.\%).

\begin{tabular}{cccccccccccc}
\hline Points & $\mathbf{O}$ & $\mathbf{A l}$ & $\mathbf{S i}$ & $\mathbf{S}$ & $\mathbf{C a}$ & $\mathbf{C r}$ & $\mathbf{M n}$ & $\mathbf{F e}$ & $\mathbf{C u}$ & $\mathbf{Z n}$ & $\mathbf{P b}$ \\
\hline P4 & 0.00 & 0.00 & 0.00 & 30.95 & 0.00 & 0.00 & 0.00 & 1.43 & 0.00 & 67.62 & 0.00 \\
P13 & 2.02 & 0.00 & 5.65 & 29.53 & 0.00 & 0.00 & 0.00 & 1.15 & 0.00 & 61.65 & 0.00 \\
P17 & 0.00 & 0.00 & 0.26 & 32.02 & 0.00 & 0.00 & 0.00 & 0.93 & 0.00 & 66.79 & 0.00 \\
\hline
\end{tabular}

Table 10. Electron microprobe analyses of selected spots from area 4 (wt.\%).

\begin{tabular}{cccccccc}
\hline Points & $\mathbf{O}$ & $\mathbf{S i}$ & $\mathbf{S}$ & $\mathbf{F e}$ & $\mathbf{C u}$ & $\mathbf{Z n}$ & $\mathbf{P b}$ \\
\hline P5 & 21.92 & 7.11 & 0.21 & 59.47 & 0.00 & 0.00 & 3.84 \\
P9 & 35.42 & 10.08 & 2.21 & 40.69 & 0.00 & 1.89 & 0.00 \\
P13 & 14.26 & 8.69 & 0.00 & 70.22 & 0.00 & 1.81 & 1.68 \\
\hline
\end{tabular}


Table 11. Electron microprobe analyses of selected spots from area 5 (wt.\%).

\begin{tabular}{cccccccc}
\hline Points & $\mathbf{O}$ & $\mathbf{S i}$ & $\mathbf{S}$ & $\mathbf{F e}$ & $\mathbf{C u}$ & $\mathbf{Z n}$ & $\mathbf{P b}$ \\
\hline P4 & 26.17 & 59.18 & 0.57 & 11.32 & 0.52 & 0.00 & 2.23 \\
P10 & 9.63 & 0.47 & 0.00 & 89.90 & 0.00 & 0.00 & 0.00 \\
P16 & 22.50 & 47.06 & 0.65 & 27.31 & 0.00 & 0.00 & 2.49 \\
\hline
\end{tabular}

Table 12. Electron microprobe analyses of selected spots from area 6 (wt.\%).

\begin{tabular}{cccccccc}
\hline Points & $\mathbf{O}$ & $\mathbf{S i}$ & $\mathbf{S}$ & $\mathbf{F e}$ & $\mathbf{C u}$ & $\mathbf{Z n}$ & $\mathbf{P b}$ \\
\hline P6 & 13.97 & 25.30 & 5.56 & 52.16 & 0.00 & 0.00 & 0.00 \\
P10 & 2.32 & 5.22 & 0.00 & 91.79 & 0.00 & 0.00 & 0.00 \\
P13 & 11.06 & 0.00 & 0.18 & 88.27 & 0.50 & 0.00 & 0.00 \\
\hline
\end{tabular}

\subsubsection{Raw Sample}

The analysis was performed for the first samples that appear in Figures 6-11. For each sample in the Figure 6, Figure 8, and Figure 10, section (a) represents the area corresponding to the element mapping analyses, while section (b) represents the areas selected for the spot analyses, and through which the proportions of the target elements in the sample are determined.

Elemental distribution maps observed by EPMA for areas 1,2, and 3 are shown in Figures 7, 9 and 11, respectively, and highlight the presence of zinc $(\mathrm{Zn})$, lead $(\mathrm{Pb})$, iron $(\mathrm{Fe})$, chromium $(\mathrm{Cr})$, copper $(\mathrm{Cu})$, calcium $(\mathrm{Ca})$, manganese $(\mathrm{Mn})$, oxygen $(\mathrm{O})$, aluminum $(\mathrm{Al})$, sulfur (S), and silicon (Si).

Tables 8-10 show electron microprobe analyses by wt.\% of selected spots from areas 1, 2 , and 3 in Figure 6 b, Figure 8b, and Figure 10b, respectively. The results show an increase in the iron percentage in area 1, while the percentage of lead increases in areas 2 and 3; the zinc ratio represents the largest proportions, along with sulfur, silica, and aluminum as secondary impurities. The values in Tables 7-9 show the weight percentages of the elements that were identified in the survey areas.
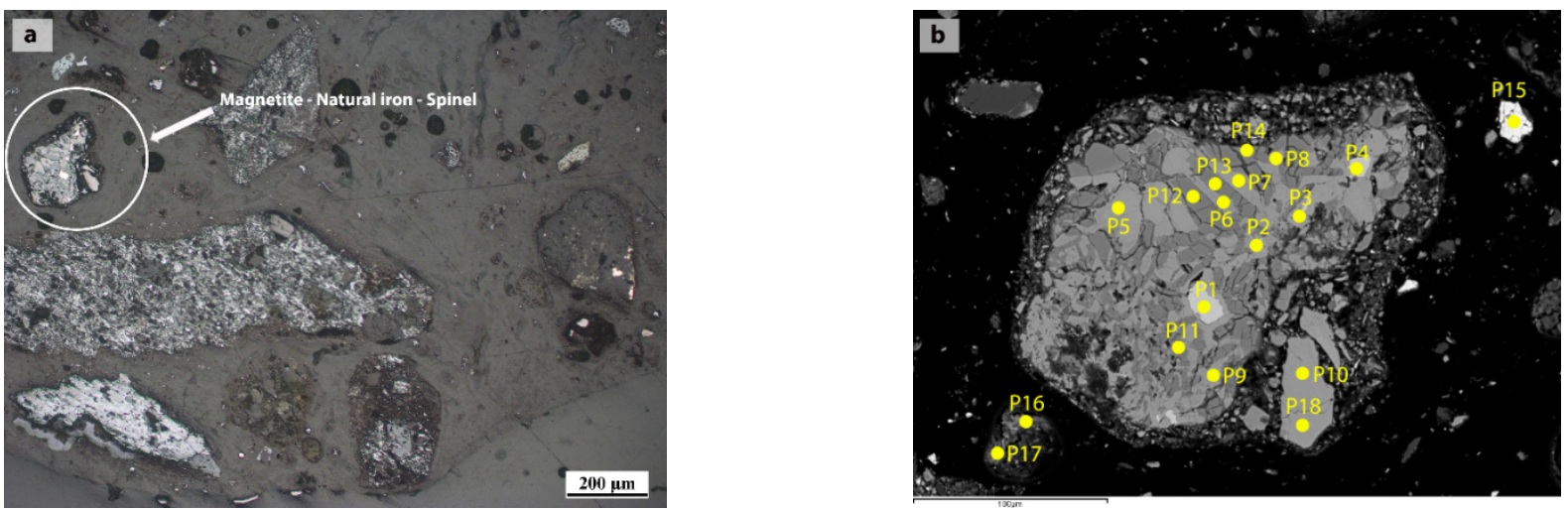

Figure 6. Electron images of EPMA showing the microstructures of area 1: (a) the area corresponding to the element mapping analyses; (b) areas selected for the spot analyses. 

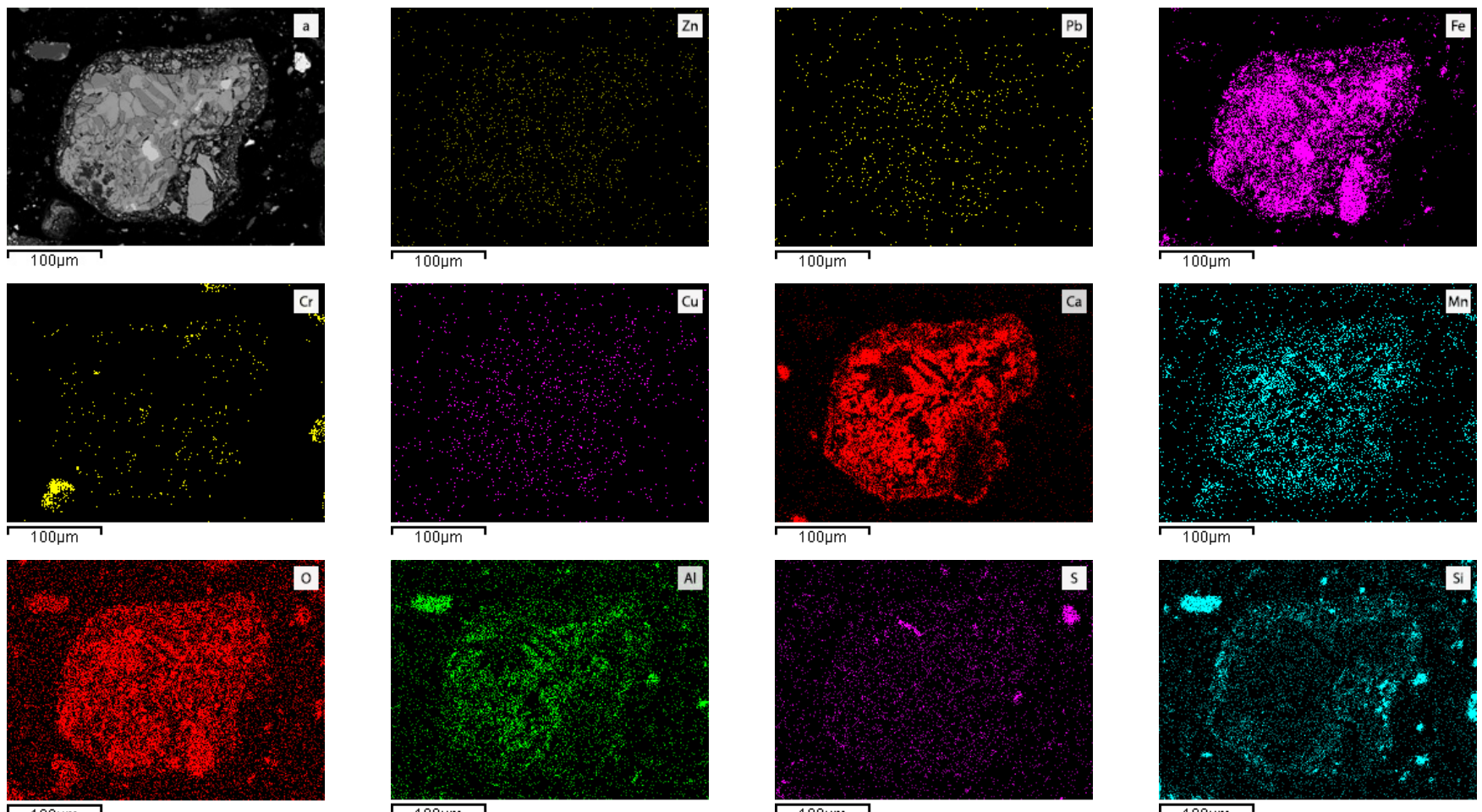

Figure 7. Elemental distribution maps observed by EPMA: area 1 (a).
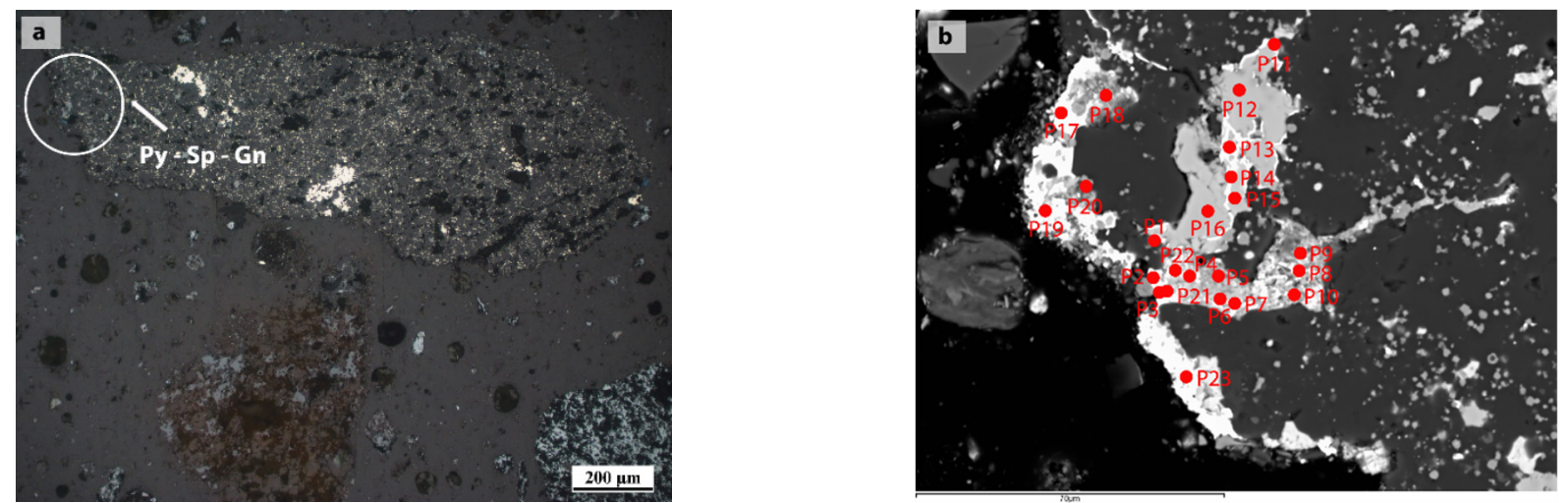

Figure 8. Electron images of EPMA showing the microstructures of area 2: (a) the area corresponding to the element mapping analyses; (b) areas selected for the spot analyses. 

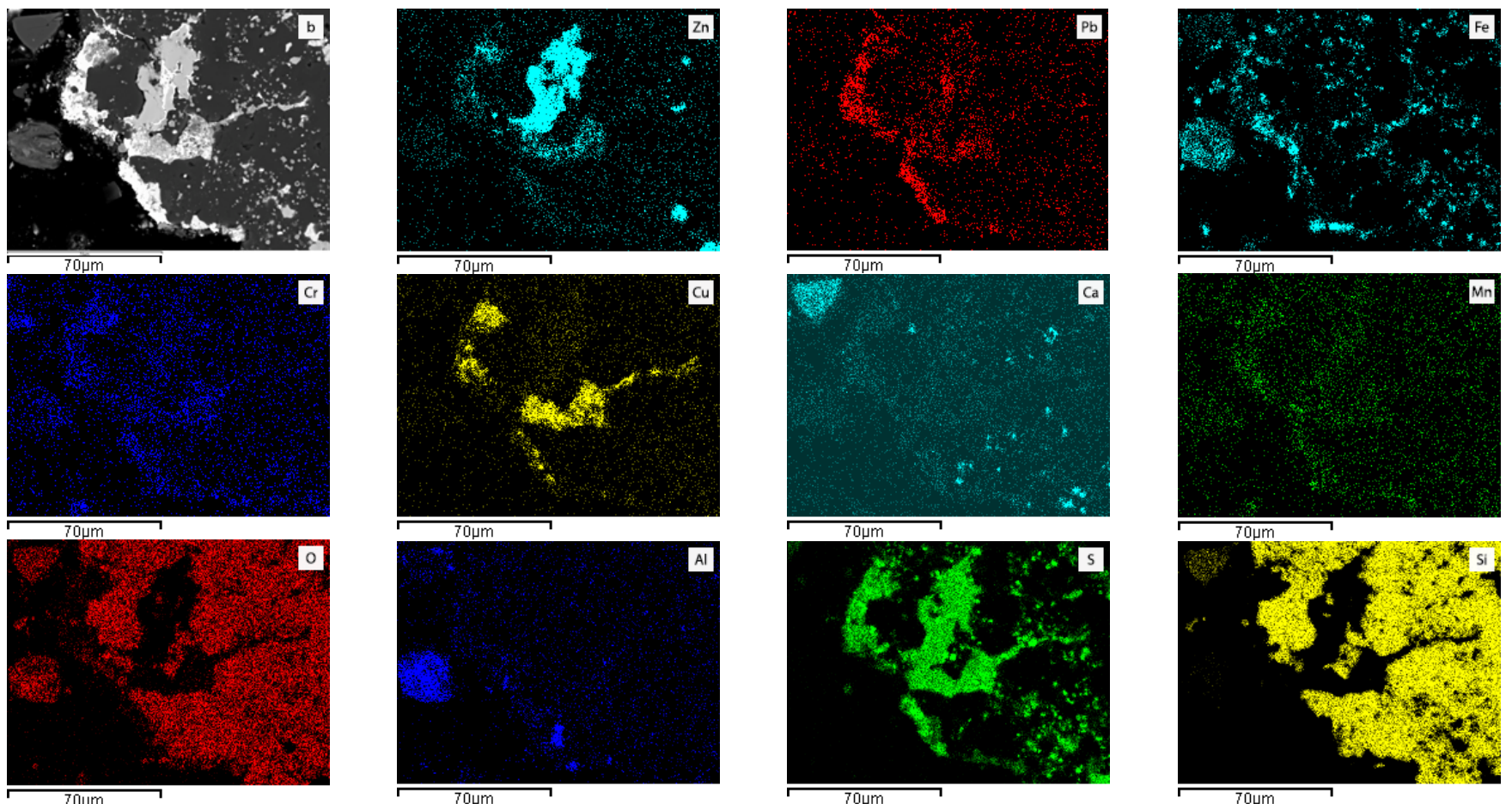

Figure 9. Elemental distribution maps observed by EPMA: area 2 (b).
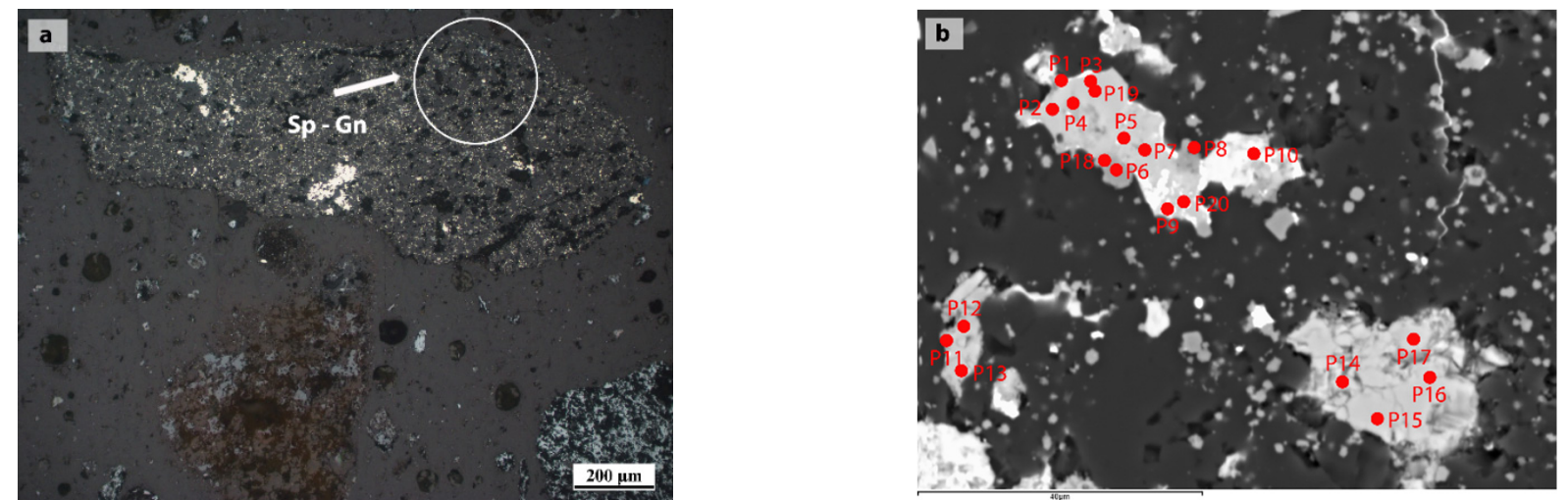

Figure 10. Electron images of EPMA showing the microstructures of area 3: (a) the area corresponding to the element mapping analyses; (b) areas selected for the spot analyses.

\subsubsection{Roasted Samples}

EPMA analysis of roasted samples was carried out after the roasting process in order to determine the elements present in the samples. The results are shown below and in Figure 12. The roasting temperature for the sample was $750{ }^{\circ} \mathrm{C}$ for $60 \mathrm{~min}$. The area specified in the circle in Figure 12a is the area corresponding to the element mapping analyses, while the area in Figure $12 \mathrm{~b}$ was selected for the spot analyses at $90 \mu \mathrm{m}$, and this region represents the presence of galena and limonite, as shown in the results of the microscopic analysis.

Elemental distribution map observed by EPMA for area 4 is shown in Figure 13. EPMA analysis of a sample that was taken at a roasting temperature of $900{ }^{\circ} \mathrm{C}$ for $60 \mathrm{~min}$, is shown in Figure 14. Figure 15 represents analysis for area 5. Further, another sample was roasted at $1200{ }^{\circ} \mathrm{C}$ for $60 \mathrm{~min}$, and EPMA analysis was performed; the results are shown in Figure 16. In the end, Figure 17 represents analysis for area 6. 

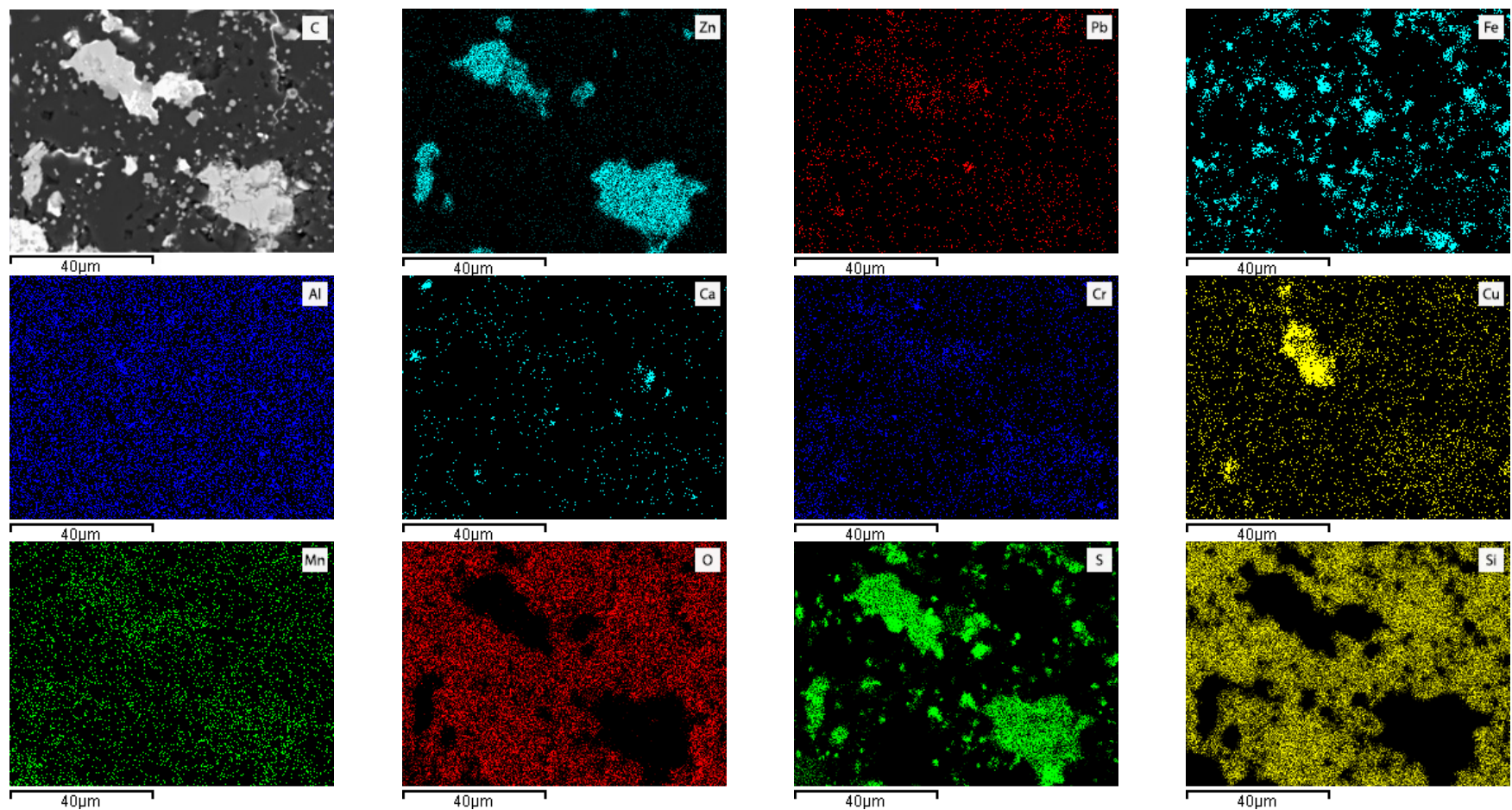

Figure 11. Elemental distribution maps observed by EPMA: area 3 (c)
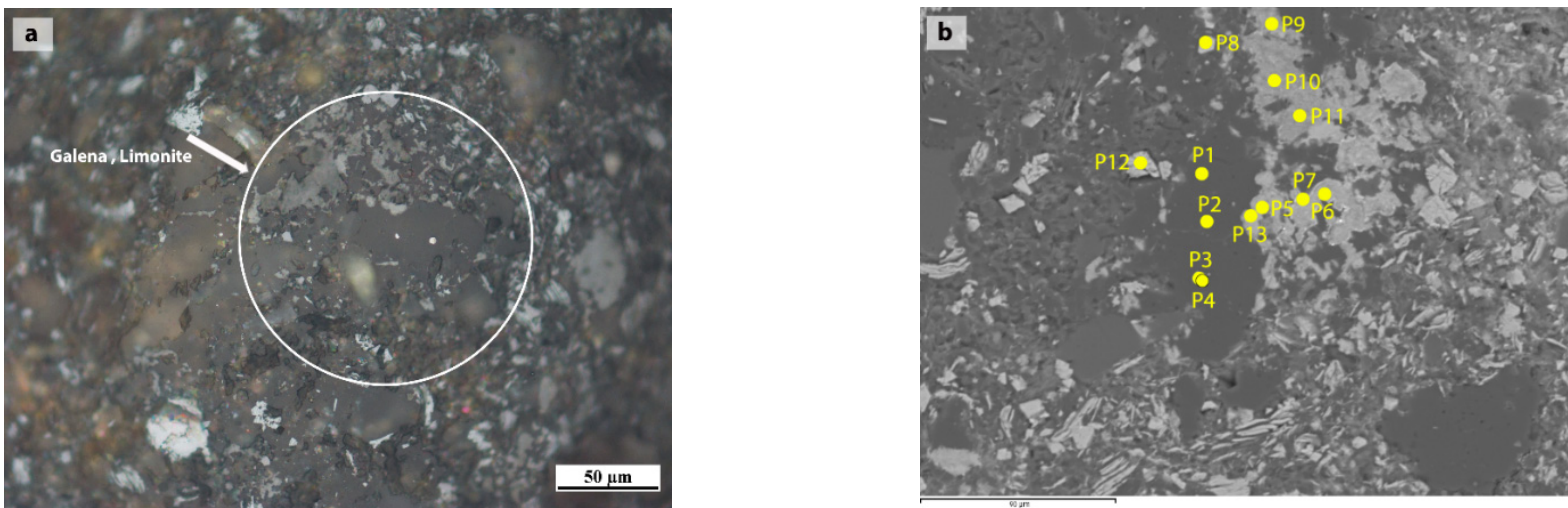

Figure 12. Electron images of EPMA showing the microstructures of area 4: (a) the area corresponding to the element mapping analyses; (b) areas selected for the spot analyses.
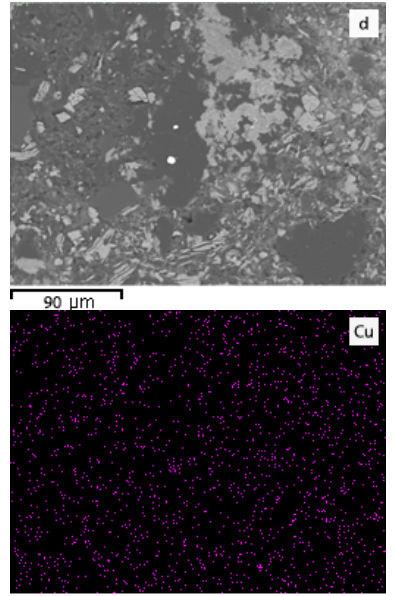

$90 \mu \mathrm{m}$
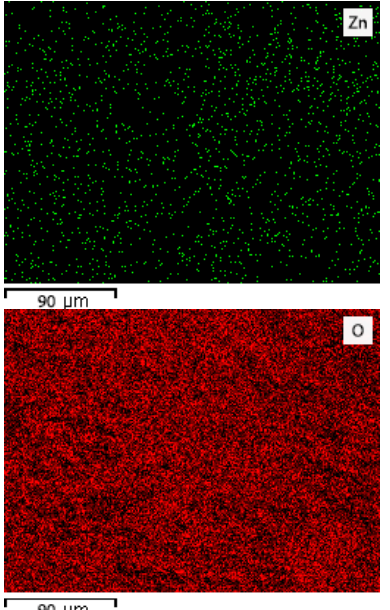

Figure 13. Elemental distribution maps observed by EPMA: area 4 (d).
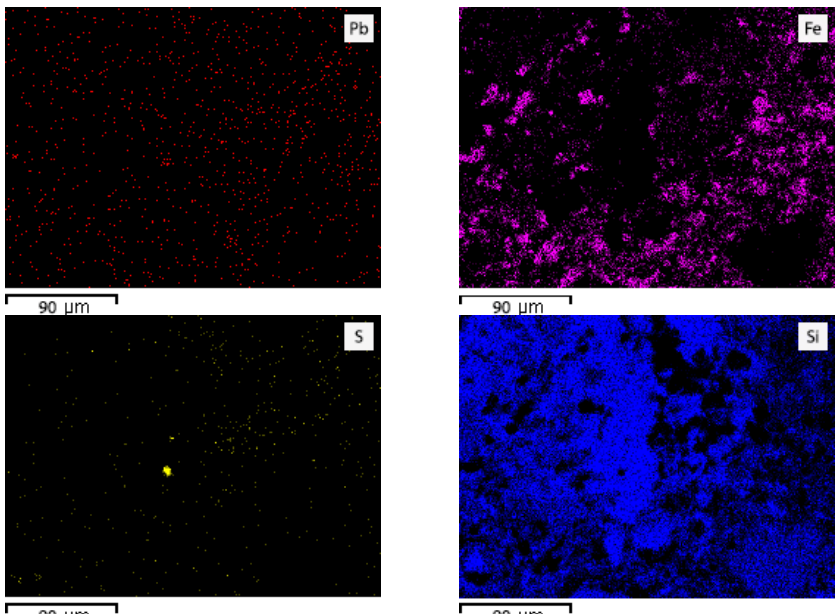

$90 \mu \mathrm{m}$ 

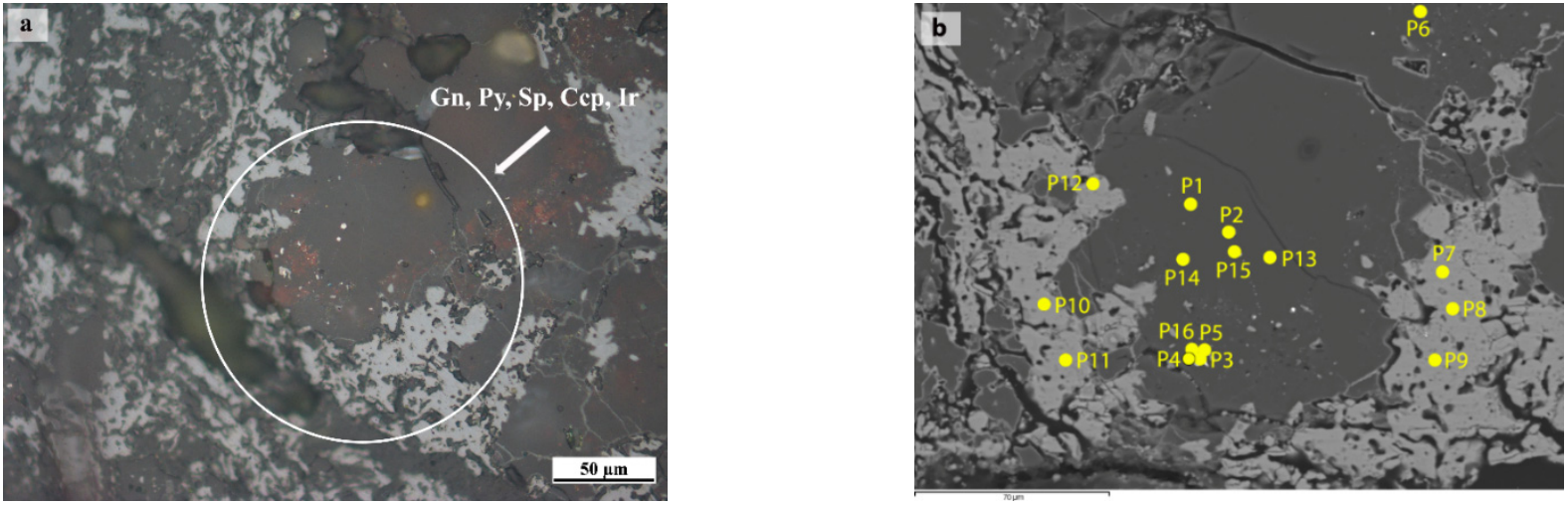

Figure 14. Electron images of EPMA showing the microstructures of area 5: (a) the area corresponding to the element mapping analyses; (b) areas selected for the spot analyses.
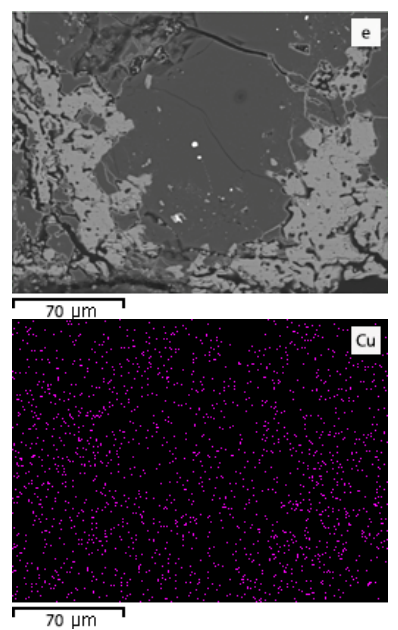
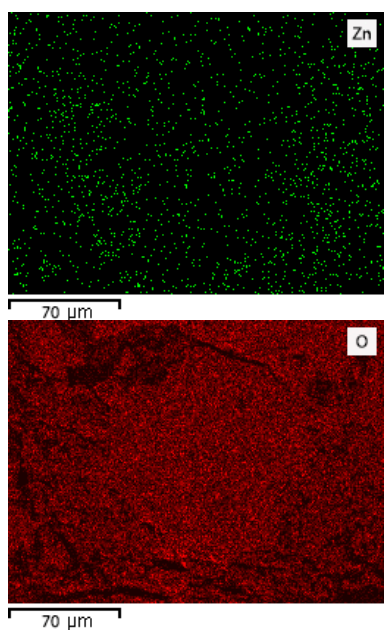
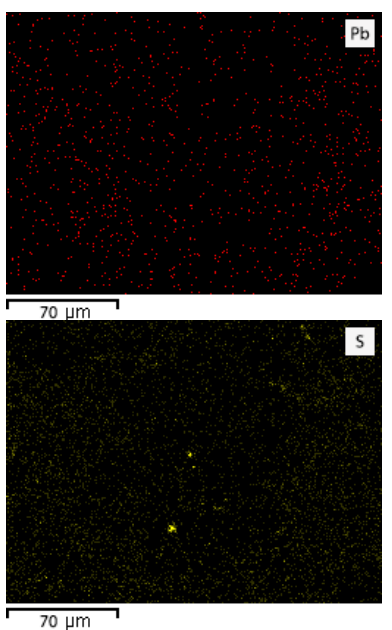
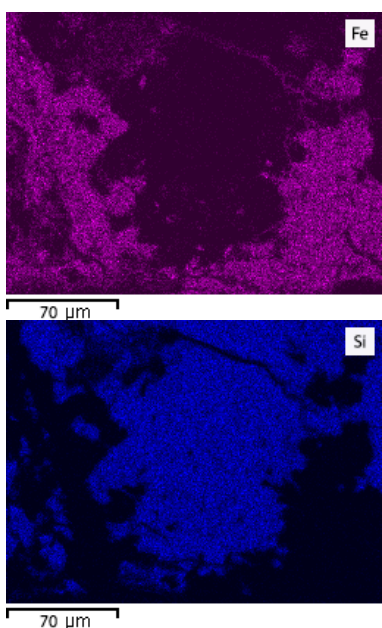

Figure 15. Elemental distribution maps observed by EPMA: area 5 (e).
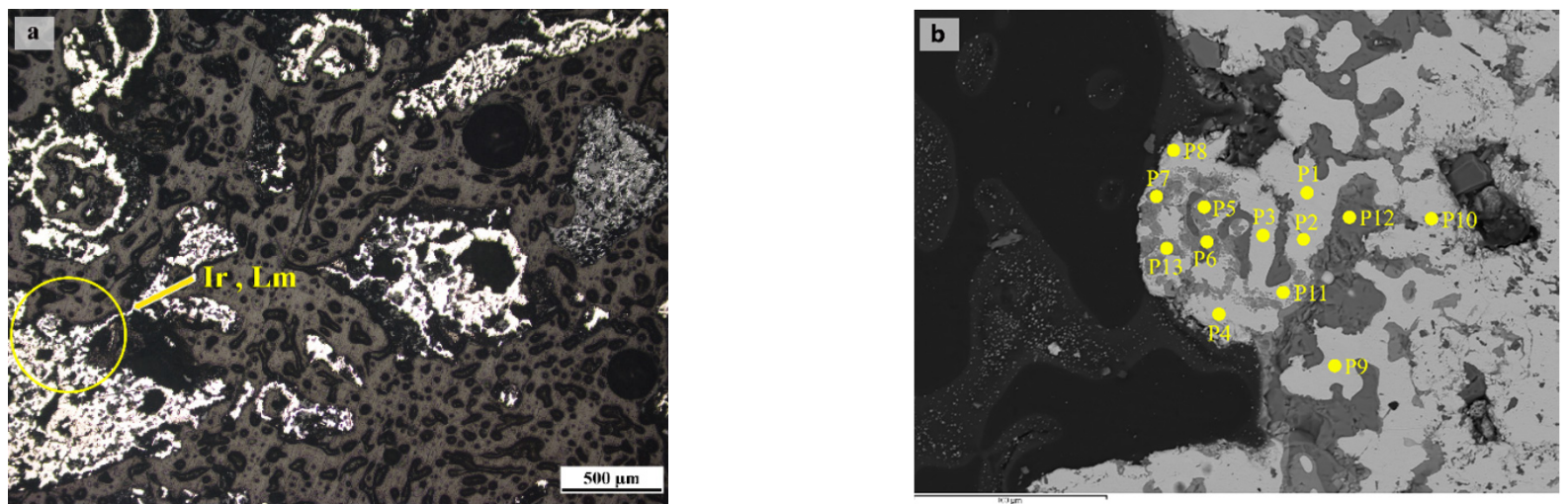

Figure 16. Electron images of EPMA showing the microstructures of area 6: (a) the area corresponding to the element mapping analyses; (b) areas selected for the spot analyses.

In Figures 13, 15 and 17 the presence of zinc $(\mathrm{Zn})$, lead $(\mathrm{Pb})$, iron $(\mathrm{Fe})$, copper $(\mathrm{Cu})$, oxygen (O), sulfur $(\mathrm{S})$, and silicon (Si) were highlighted. The values in Tables 10-12 show the weight percentages of the elements that were observed in the survey areas.

During reduction roasting, hematite was reduced to magnetite through a solid-state reaction, and the particle sizes of Fe-bearing minerals showed no significant differences before and after roasting. In comparison, deep reduction achieved the full reduction of hematite into metallic iron, and promoted the increase in the particle size of metallic iron. 

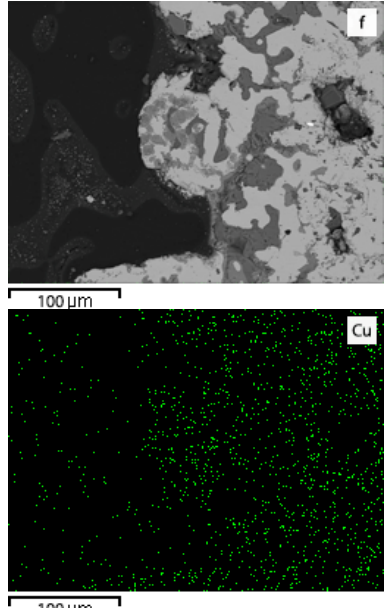

$100 \mu \mathrm{m}$
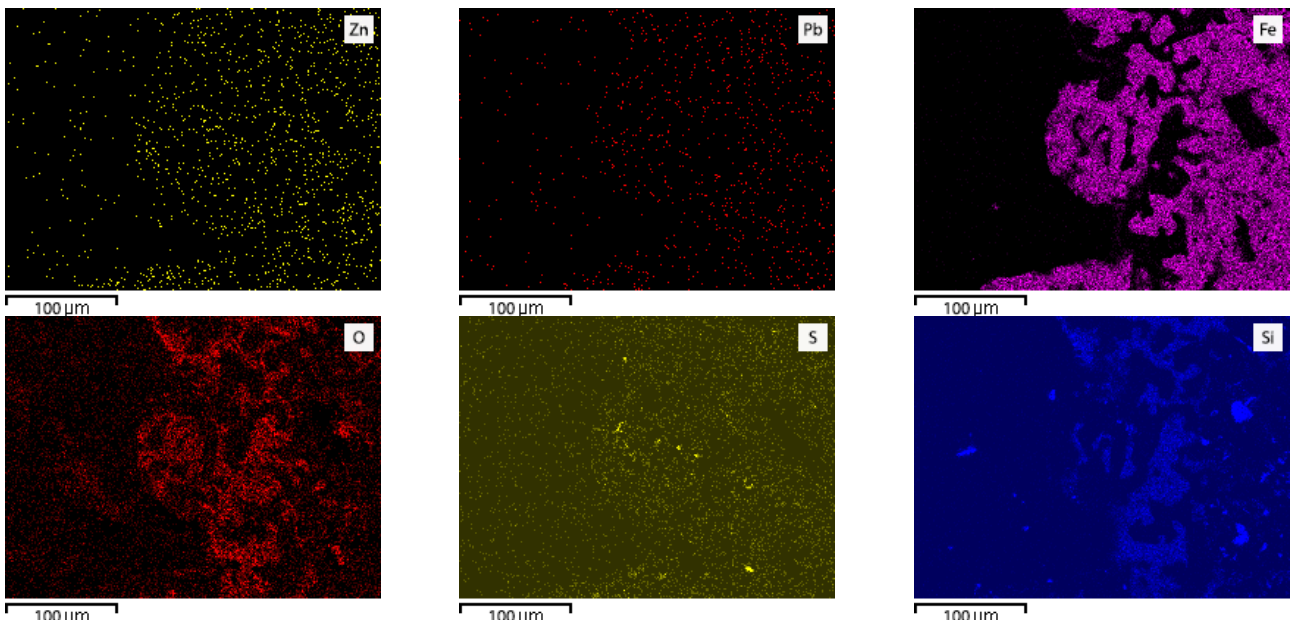

$100 \mu \mathrm{m}$

Figure 17. Elemental distribution maps observed by EPMA: area 6 (f).

The corresponding chemical reactions are as shown in Equations (1)-(3). At the same time, the lead and zinc impurities contained in iron ore will simultaneously undergo oxidation and reduction reactions during the roasting process, as shown in Equations (4)-(8). Although the boiling points of elemental lead and zinc are $1749^{\circ} \mathrm{C}$ and $907^{\circ} \mathrm{C}$, respectively, when the temperature is low, elemental lead is highly volatile, and flows away with the air. The sulfide of zinc is first converted to oxides, and then reduced to gaseous zinc in the high-temperature zone above $1000^{\circ} \mathrm{C}$, and enters the gas system. Alternatively, lead and zinc are dissolved in the water-quenching liquid to achieve the purpose of removing harmful impurities.

When the temperature is greater than $570^{\circ} \mathrm{C}$, the reaction as shown in Equation (1) begins:

$$
3 \mathrm{Fe}_{2} \mathrm{O}_{3}+\mathrm{CO} \rightarrow \mathrm{Fe}_{3} \mathrm{O}_{4}+\mathrm{CO}_{2}
$$

When the temperature is greater than $1000^{\circ} \mathrm{C}$, the main chemical reactions that occur are as follows:

$$
\begin{gathered}
\mathrm{Fe}_{3} \mathrm{O}_{4}+\mathrm{CO} \rightarrow 3 \mathrm{FeO}+\mathrm{CO}_{2} \\
\mathrm{FeO}+\mathrm{CO} \rightarrow \mathrm{Fe}+\mathrm{CO}_{2}
\end{gathered}
$$

When the calcination temperature is $500 \sim 800{ }^{\circ} \mathrm{C}$, the oxidation reaction will occur first, and then the reduction reaction will occur:

$$
\begin{gathered}
2 \mathrm{PbS}+3 \mathrm{O}_{2}=2 \mathrm{PbO}+2 \mathrm{SO}_{2} \\
\mathrm{PbO}+\mathrm{CO}=\mathrm{Pb}+\mathrm{CO}_{2}
\end{gathered}
$$

If the reduction temperature reaches $950{ }^{\circ} \mathrm{C}$ :

$$
2 \mathrm{ZnS}+3 \mathrm{O}_{2}=2 \mathrm{ZnO}+2 \mathrm{SO}_{2}
$$

When the temperature is above $1000^{\circ} \mathrm{C}$ :

$$
\begin{gathered}
\mathrm{ZnO}+\mathrm{C}=\mathrm{Zn}+\mathrm{CO} \\
\mathrm{ZnO}+\mathrm{Fe}=\mathrm{Zn}+\mathrm{FeO}
\end{gathered}
$$

\subsection{EDS Analysis}

In order to examine the elemental compositions and equivalent contents in "microzones" of the scanning areas, EDS was carried out to conduct energy spectrum analysis for the micro-zones of hematite, magnetite, sphalerite, chalcopyrite, quartz, and galena. 
According to analysis results by EDS in Tables 8-10, the surfaces show high contents of lead, zinc, manganese, quartz, and sulfur, meaning that they represent the main impurities identified in hematite and magnetite. This constant is also observed in Figure 18b,c, where the peaks of lead, zinc, manganese, sulfur, and silicon are found.
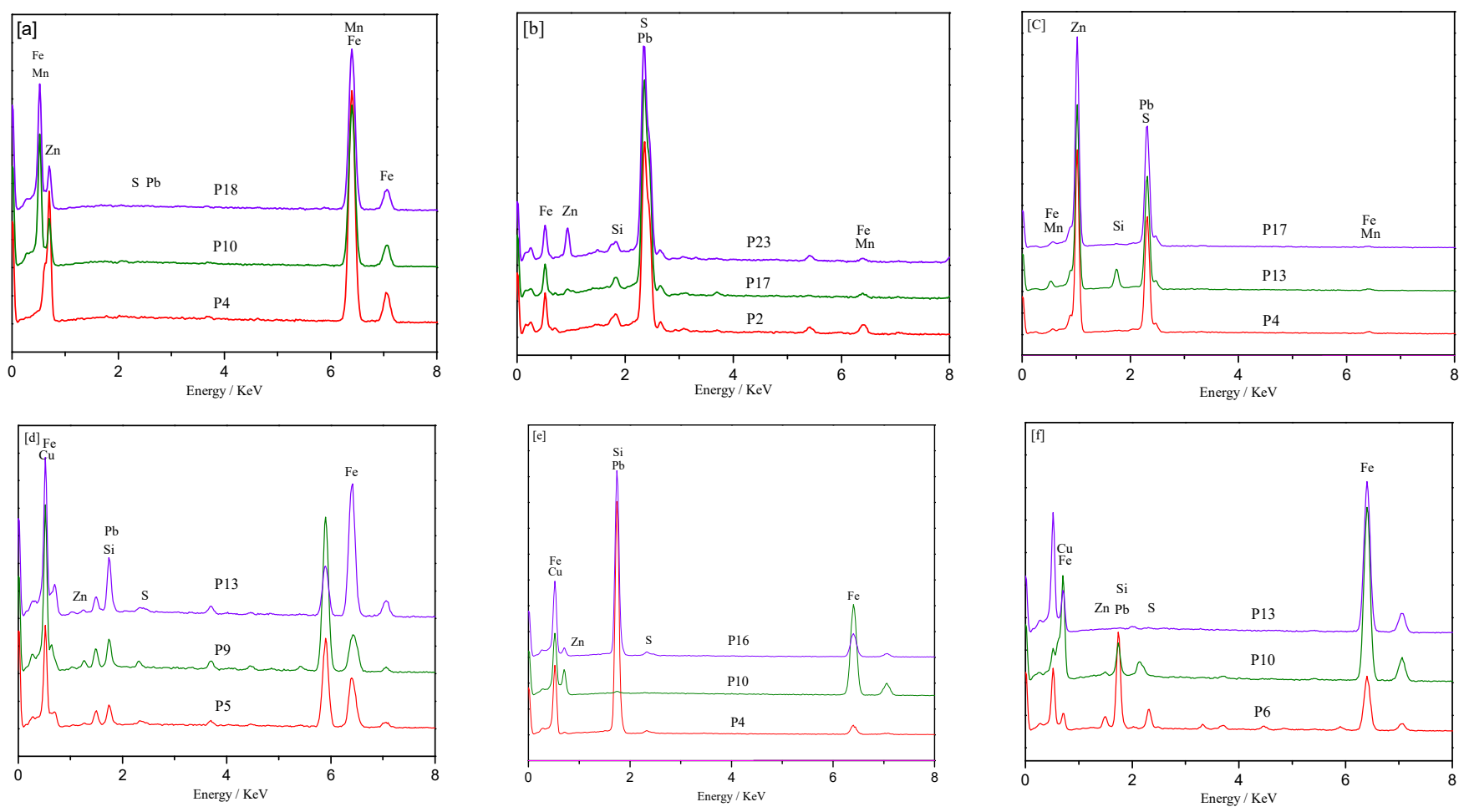

Figure 18. EDS spectra of different micro-zones: (a) Fe micro-zone; (b) Pb micro-zone; (c) Zn microzone; (d) roasting temperature $750{ }^{\circ} \mathrm{C}$; (e) roasting temperature $900{ }^{\circ} \mathrm{C}$; (f) roasting temperature $1200{ }^{\circ} \mathrm{C}$.

It should be noted that the percentages of sulfur, lead, and zinc decreased significantly after roasting, as shown in Tables 10-12 and the EDS curves shown in Figure 18d-f, while the percentages of impurities decreased whenever the roasting temperature increased from $750{ }^{\circ} \mathrm{C}$ to $1200{ }^{\circ} \mathrm{C}$.

\subsection{Effects of Reduction Roasting Temperature}

To determine the optimal reduction roasting temperature, the refractory iron ore containing lead and zinc was reduced at various temperatures between $750{ }^{\circ} \mathrm{C}$ and $1200{ }^{\circ} \mathrm{C}$, while keeping other process parameters constant; the amount of reducing agent was $11 \%$ under low-temperature conditions (the molar ratio of C:O selected during the hightemperature stage was 1.5), and the reduction roasting time was $1 \mathrm{~h}$. The effects of the reduction roasting temperature on the iron recovery are presented in Figure 19.

It can be seen from Figure 19 that the reduction roasting temperatures of $800{ }^{\circ} \mathrm{C}$ and $1200{ }^{\circ} \mathrm{C}$ obtained better iron recovery, and the magnetic separation concentrates of the iron grade and iron recovery were $56.66 \%, 90.51 \%$ and $92.39 \%, 76.86 \%$, respectively. The reduction roasting temperature has a greater impact on the iron grade and iron recovery rate of the magnetic separation concentrates. As the reduction roasting temperature increases, the concentration of carbon monoxide in the system continuously increases, and the iron oxide is gradually reduced to elemental iron, which makes the iron grade of the magnetic separation concentrate continuously increase. 


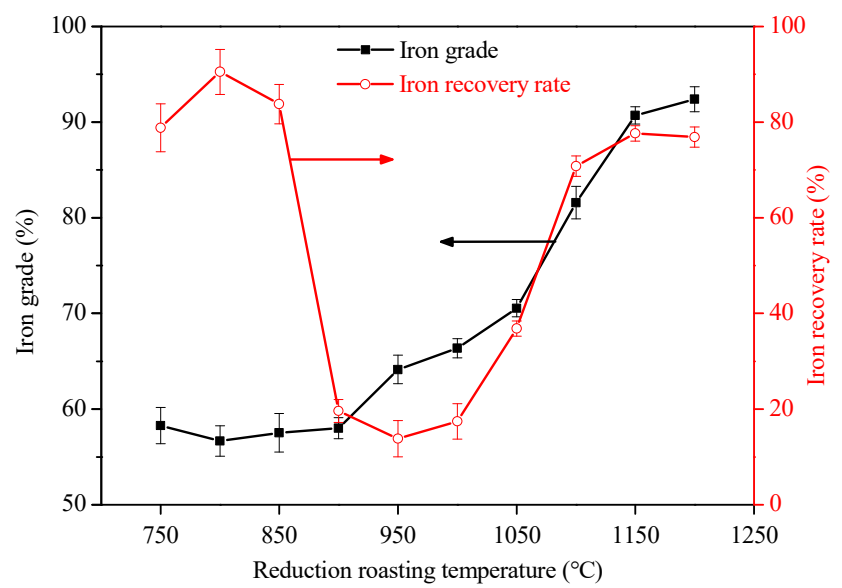

Figure 19. Effects of reduction roasting temperature on magnetic separation concentrate indicators.

\section{Conclusions}

1. Rock and mineral identification and phase in the micro-zone analysis show that hematite is the main iron-bearing mineral, accounting for up to $91.35 \%$ of iron, with small amounts of magnetite and iron silicate; lead impurities are mainly lead oxide and lead-iron, accounting for $49.03 \%$ and $41.29 \%$, respectively; zinc oxide is the main zinc impurity, accounting for $90.60 \%$; lead-zinc sulfide is less abundant, accounting for $7.2 \%$ and $5.7 \%$, indicating that the lead-zinc complex in the hematite is mainly composed of oxidized lead-zinc minerals;

2. XRF analysis for raw samples indicated the presence of quartz, hematite, magnetite, chlorite, calcite, and dolomite. The analysis showed that the percentage of hematite in the ore is high compared to the percentages of quartz, lead, and zinc impurities. The results of the analysis of roasted samples showed an increase in the percentage of hematite at roasting temperatures of $750{ }^{\circ} \mathrm{C}$ and $900{ }^{\circ} \mathrm{C}$, while the natural iron percentage increased at a temperature of $1200^{\circ} \mathrm{C}$, along with the conversion of galena to lead oxide and sphalerite to zinc oxide, with a stable quartz ratio;

3. The chemical analysis of the raw sample shows that the TFe of the sample is $47.04 \%$, while the contents of harmful $\mathrm{Pb}$ and $\mathrm{Zn}$ impurities are $0.39 \%$ and $0.30 \%$, respectively, both of which exceed the index of $0.10 \%$ required from raw materials in the iron industry. The content of harmful sulfur impurities is also high $(1.19 \%)$, and needs to be eliminated or reduced. The contents of the gangue mineral components $\mathrm{SiO}_{2}$ and $\mathrm{Al}_{2} \mathrm{O}_{3}$ are $20.33 \%$ and $2.85 \%$, respectively;

4. The results of EPMA and EDS analysis of pre-roasting raw samples showed that the chemical compositions vary in different locations in the hematite, magnetite, sphalerite, and galena micro-zones. A high iron content is present in the hematite and magnetite micro-zones, while the lead and zinc contents are high in other microscopic regions, as the main impurities in the ore. It was also observed that quartz is mostly diffused with magnetite and hematite, and sulfur appears in small quantities in most regions. The analysis after roasting showed that the percentages of lead, zinc, and sulfur impurities decreased by a large rate, meaning that the roasting process before processing may have a clear effect in removing impurities and reducing their percentages;

5. From the results of the chemical analysis, X-ray diffraction, and EPMA, it is clear that the roasting process plays a key role in removing impurities such as sulfur-which appears in small quantities after the roasting process-and also helps in oxidizing the impurities of lead and zinc, which helps in removing them;

6. From the results, it can be observed that the roasting of iron ore containing impurities of lead and zinc and quantities of sulfur is important before ironmaking; it is necessary to adjust the temperatures and time periods with an appropriate degree of release. 


\begin{abstract}
Author Contributions: B.Z. and C.W. played important roles in preparing the samples for analysis; N.C. played a role in reviewing the linguistic and coordination errors in the paper; L.L. is the corresponding author, and was the primary supervisor of the research, operations, and review of experiments; S.M. was responsible for the rest of the study, related to the corresponding mineralogical and chemical characterization after reduction roasting of Xinjiang iron ore. All authors have read and agreed to the published version of the manuscript.
\end{abstract}

Funding: This work was funded by the National Natural Science Foundation of China (No.: 51874219).

Institutional Review Board Statement: Not applicable.

Informed Consent Statement: Not applicable.

Data Availability Statement: Not applicable.

Acknowledgments: The authors would also like to thank the Wuhan University of Technology for providing information and guidance.

Conflicts of Interest: The authors declare no conflict of interest.

\title{
References
}

1. Wills, B.A.; Napier-Munn, T. 1-Introduction. In Wills' Mineral Processing Technology, 7th ed.; Wills, B.A., Napier-Munn, T., Eds.; Butterworth-Heinemann: Oxford, UK, 2005; pp. 1-29. [CrossRef]

2. Holmes, R.J.; Lu, L. 1-Introduction: Overview of the global iron ore industry. In Iron Ore; Lu, L., Ed.; Woodhead Publishing: Sawston, Cambridge, UK, 2015; pp. 1-42. [CrossRef]

3. Fisher, L.V.; Barron, A.R. The recycling and reuse of steelmaking slags-A review. Resour. Conserv. Recycl. 2019, 146, $244-255$. [CrossRef]

4. Ponomar, V.P.; Dudchenko, N.O.; Brik, A.B. Reduction roasting of hematite to magnetite using carbohydrates. Int. J. Miner. Process. 2017, 164, 21-25. [CrossRef]

5. Chen, H.; Wan, B.; Pirajno, F.; Chen, Y.; Xiao, B. Metallogenesis of the Xinjiang Orogens, NW China-New discoveries and ore genesis. Ore Geol. Rev. 2018, 100, 1-11. [CrossRef]

6. Mustafa, S.; Luo, L.; Zheng, B.-T.; Wei, C.-X.; Christophe, N. Effect of Lead and Zinc Impurities in Ironmaking and the Corresponding Removal Methods: A Review. Metals 2021, 11, 407. [CrossRef]

7. Trinkel, V.; Aschenbrenner, P.; Thaler, C.; Rechberger, H.; Mallow, O.; Fellner, J. Distribution of Zn, Pb, K, and Cl in Blast Furnace Lining. Steel Res. Int. 2017, 88, 1600153. [CrossRef]

8. Bhateria, R.; Singh, R. A review on nanotechnological application of magnetic iron oxides for heavy metal removal. J. Water Process Eng. 2019, 31, 100845. [CrossRef]

9. Zhang, D.; Zhang, X.; Yang, T.; Rao, S.; Hu, W.; Liu, W.; Chen, L. Selective leaching of zinc from blast furnace dust with mono-ligand and mixed-ligand complex leaching systems. Hydrometallurgy 2017, 169, 219-228. [CrossRef]

10. Min, X.-B.; Xie, X.-D.; Chai, L.-Y.; Liang, Y.-J.; Li, M.; Ke, Y. Environmental availability and ecological risk assessment of heavy metals in zinc leaching residue. Trans. Nonferrous Met. Soc. China 2013, 23, 208-218. [CrossRef]

11. Yang, X.F.; Chu, M.S.; Shen, F.M.; Zhang, Z.M. Mechanism of zinc damaging to blast furnace tuyere refractory. Acta Metall. Sin.-Engl. Lett. 2009, 22, 454-460. [CrossRef]

12. Jiao, K.X.; Zhang, J.L.; Liu, Z.J.; Chen, C.L.; Liu, F. Circulation and accumulation of harmful elements in blast furnace and their impact on the fuel consumption. Ironmak. Steelmak. 2017, 44, 344-350. [CrossRef]

13. Mikhailov, I.; Komarov, S.; Levina, V.; Gusev, A.; Issi, J.P.; Kuznetsov, D. Nanosized zero-valent iron as Fenton-like reagent for ultrasonic-assisted leaching of zinc from blast furnace sludge. J. Hazard. Mater. 2017, 321, 557-565. [CrossRef] [PubMed]

14. Esezobor, D.E.; Balogun, S.A. Zinc accumulation during recycling of iron oxide wastes in the blast furnace. Ironmak. Steelmak. 2006, 33, 419-425. [CrossRef]

15. Kumar, M.; Jena, S.; Patel, S.K. Characterization of properties and reduction behavior of iron ores for application in sponge ironmaking. Miner. Process. Extr. Metall. Rev. 2008, 29, 118-129. [CrossRef]

16. Jung, Y.H.; Baik, S.J.; Ahn, S.B. Investigation of Zircaloy-fuel interaction in failed spent PWR fuel using EPMA. J. Nucl. Mater. 2019, 517, 349-355. [CrossRef]

17. Rath, S.S.; Rao, D.S.; Mishra, B.K. A novel approach for reduction roasting of iron ore slime using cow dung. Int. J. Miner. Process. 2016, 157, 216-226. [CrossRef]

18. Li, M.; Peng, B.; Chai, L.; Peng, N.; Yan, H.; Hou, D. Recovery of iron from zinc leaching residue by selective reduction roasting with carbon. J. Hazard. Mater. 2012, 237-238, 323-330. [CrossRef] [PubMed]

19. Luong, V.T.; Kang, D.J.; An, J.W.; Dao, D.A.; Kim, M.J.; Tran, T. Iron sulphate roasting for extraction of lithium from lepidolite. Hydrometallurgy 2014, 141, 8-16. [CrossRef]

20. Peng, T.F.; Gao, X.C.; Li, Q.B.; Xu, L.J.; Luo, L.Q.; Xu, L.H. Phase transformation during roasting process and magnetic beneficiation of oolitic-iron ores. Vacuum 2017, 146, 63-73. [CrossRef]

21. Zhang, Y.; Yu, X.; Li, X. Zinc recovery from franklinite by sulphation roasting. Hydrometallurgy 2011, 109, 211-214. [CrossRef] 